\title{
Long-term Prognostic Impact of Chromosome Abnormalities in Clear Cell Renal Cell Carcinoma
}

\author{
CARLOTTA PALUMBO $^{1}$, MARIA FURLAN ${ }^{1}$, PIERA BALZARINI $^{2}$, TIZIANO ZANOTELLI ${ }^{1}$, \\ ALBERTO COZZOLI ${ }^{1}$, ALESSANDRO VECCIA ${ }^{1}$, SIMONE FRANCAVILLA $^{1}$, \\ STEFANIA ZAMBONI ${ }^{1}$, REGINA TARDANICO $^{2}$, CLAUDIO SIMEONE $^{1}$ and ALESSANDRO ANTONELLI ${ }^{1}$ \\ ${ }^{1}$ Urology Unit, ASST Spedali Civili of Brescia. Department of Medical and Surgical Specialties, \\ Radiological Science and Public Health, University of Brescia, Brescia, Italy; \\ ${ }^{2}$ Department of Molecular and Translational Medicine, Section of Anatomic Pathology, \\ Oncology and Experimental immunology, University of Brescia, Brescia, Italy
}

\begin{abstract}
Background/Aim: Clear cell renal cell carcinoma (ccRCC) shows variable chromosomal abnormalities. The aim of this study was to assess the prognostic role of ccRCC chromosomal abnormalities in a single-center cohort with an extended follow-up. Materials and Methods: A systematic cytogenetic analysis was performed in 283 consecutive surgically-treated patients for renal masses between 1997 and 2002. Kaplan-Meier and multivariable Cox regression (MCR) models were used to calculate cancer specific survival (CSS). Results: Among 174 ccRCC patients, the most common abnormality was deletion in chromosome 3 (54.6\%). At a median follow-up of 119 months, 38 patients (21.8\%) died from RCC. At MCR models, worse CSS was independently predicted by deletions in chromosomes 2, 19, 20 or 22 and insertions in chromosome 18. Conclusion: Specific ccRCC chromosomal abnormalities are independently associated with worse CSS. Cytogenetic evaluation may direct further genetic analysis for personalized prognostic stratification.
\end{abstract}

Renal cell carcinoma (RCC) encompasses a heterogeneous group of cancers derived from renal tubular epithelial cells. In 2016, the World Health Organization provided a revision of renal tumor histologies, which included 15 additional subtypes. Among these, clear cell RCC (ccRCC) histology accounts for more than $75 \%$ of cases (1).

Correspondence to: Alessandro Antonelli, MD, Professor of Urology, Urology Unit, ASST Spedali Civili of Brescia, Department of Medical and Surgical Specialties, Radiological Science and Public Health, University of Brescia, Piazzale Spedali Civili 1, 25123, Brescia, Italy. Tel: +39 3382503843, Fax: +39 0303995055 , e-mail: alessandro_antonelli@me.com

Key Words: Renal cell carcinoma, clear cell, karyotype, chromosome imbalance, prognosis, survival.
The karyotype analysis of RCC stemmed from familiar cases and then spurred a comprehensive classification of renal tumors that represented an oncological milestone (2). Indeed, each RCC entity was defined by the combination of distinct phenotypic, chromosomal and genetic features $(3,4)$. In addition to specific chromosomal abnormalities, classical cytogenetics may also reveal a diverse set of chromosomal abnormalities, broadly representative of the biological complexity of the tumor. Some of these alterations have been associated with survival outcomes (4-10). Nonetheless, previous studies have reported inconsistent findings and relied on a median follow-up ranging from 25 (6) to 73 (5) months, too short to encompass the long period during which poorly aggressive RCC, that accounts for more than half of cases $(5,9)$, may recur $(11,12)$.

In 2010 a preliminary study reported on the prognostic role of chromosomal imbalances in ccRCC (5), relying on a median follow-up time of 67 months. In the present study, the cohort was followed-up for twice as long to assess the prognostic role of chromosomal abnormalities.

\section{Materials and Methods}

Cytogenetic tumor analysis of 283 consecutive surgically-treated renal masses during the period 1997 to 2002 was performed at our institution. This project was approved by the institutional review board of Spedali Civili Hospital of Brescia. Indication to either radical or partial nephrectomy followed contemporary international guidelines. All specimens were analyzed by one experienced uropathologist (R.T.). Follow-up was conducted at a dedicated outpatient office, following an institutional schedule tailored to histopathological findings (13). All cytogenetic analyses were performed by one experienced cytogeneticist (P.B.), as previously described (5).

Covariates consisted of age, gender, side, tumor, nodes and metastases (TNM) stage, tumor size, Fuhrman grade and sarcomatoid features. For the purposes of this study, description of chromosomal abnormalities was coded as "insertion" or "deletion" of chromosomes. 
The primary endpoint of the study was cancer-specific survival (CSS), defined as death due to RCC. Chromosomal abnormalities were coded as binary variables (imbalance present vs. absent). The association between each imbalance and adverse pathological features (metastatic stage, Fuhrman grade and sarcomatoid features) was reported by univariate logistic regression models. KaplanMeier analyses and long-rank method were used to examine the association of CSS with the abnormalities. Differences in CSS were further tested in univariate and multivariate Cox regression models. Adjustment variables consisted of TNM stage, Fuhrman grade and sarcomatoid features. Finally, all survival analyses were repeated in the subgroup of patients with abnormal karyotype - i.e. including those cases with at least a chromosomal abnormality - as sensitivity analyses. All statistical tests were two-sided and the level of significance was set at $p<0.05$. Analyses were performed using the $\mathrm{R}$ software environment for statistical computing and graphics (version 3.4.1; http://www.r-project. org/).

\section{Results}

Out of 283 surgically-treated patients, between 1997 and 2002 , the cytogenetic tumor analysis data of 174 patients were analyzed. Median age was 63.5 years (interquartile range $[\mathrm{IQR}]=54.2-71), 102(58.6 \%)$ patients were male and $146(83.9 \%)$ were treated with radical nephrectomy (Table I).

The median number of chromosomal abnormalities for each case was 3.0 (IQR 0.25-6.0, range=0-24.0). The most frequent chromosomal abnormalities (Figure 1) were loss in chromosome 3 ( 95 cases, $54.6 \%$ ), loss in chromosome Y (30 cases, $17.2 \%)$, loss in chromosome 14 (28 cases, $16.1 \%$ ) and insertions in chromosome 7 ( 28 cases, $16.1 \%$ ). Specifically, deletions in chromosome 3 corresponded to 56 cases of complete loss of a single chromosome and 41 and 12 cases of chromosomal segment deletion in the short and long arms, respectively.

At univariate logistic regression models, a statistically significant association was recorded between metastatic stage (M1 vs. M0) and deletions in chromosome 9 (odds ratio [OR] 9.3, $p=0.005)$, between high Fuhrman grade (G3/G4) and deletions in chromosomes $6(\mathrm{OR}=5.9, p=0.02), 10$ $(\mathrm{OR}=9.4, p=0.04), 11(\mathrm{OR}=5.0, p=0.04)$, and $\mathrm{Y}$ (within the male cohort $\mathrm{OR}=3.1, p=0.02$ ), and insertions in chromosome $5(\mathrm{OR}=3.7, p=0.005)$ and between sarcomatoid features and deletions in chromosomes $2(\mathrm{OR}=4.3, p=0.02)$ and 18 (OR=3.9, $p=0.03$ ).

At a median follow-up time of 119.0 months (IQR=53.7154.5), 38 patients (21.8\%) died due to RCC. Kaplan-Meier plots showed a significantly worse CSS in the presence of the following chromosomal abnormalities (Figure 2A-F): deletions in chromosomes 2 (log-rank $p<0.001), 19$ (logrank $p<0.001), 20$ (log-rank $p=0.005)$ and 22 (log-rank $p=0.01$ ) and insertions in chromosomes 10 (log-rank $p=0.02$ ) and 18 (log-rank $p=0.02$ ). At multivariable Cox regression models predicting CSS (Table II), deletions in chromosome 2 (hazard ratio [HR] 7.5, $p<0.001$ ), in
Table I. Descriptive characteristics of 174 surgically-treated clear cell renal cell carcinoma patients.

\begin{tabular}{ll}
\hline Variable & Number $(\%)$ \\
\hline Age, years & \\
Median (interquartile range) & $63.5(54.2-71)$ \\
Gender & $102(58.6)$ \\
Male & $72(41.4)$ \\
Female & \\
Surgery & $146(83.9)$ \\
Radical nephrectomy & $28(16.1)$ \\
Partial nephrectomy & \\
T stage & $101(58.1)$ \\
T1 & $16(9.2)$ \\
T2 & $54(31.0)$ \\
T3 & $3(1.7)$ \\
T4 & $171(98.3)$ \\
N stage & $3(1.7)$ \\
N0/NX & \\
N1 & $25(14.4)$ \\
M stage & \\
M1 & $11(6.3)$ \\
Fuhrman grade & $58(33.3)$ \\
G1 & $71(40.8)$ \\
G2 & $34(19.5)$ \\
G3 & $5.0(3.4-7.0)$ \\
G4 & $34(19.5)$ \\
Size, mm & $16(9.2)$ \\
Median (interquartile range) & \\
Thrombus & $19(10.9)$ \\
Present & \\
Necrosis & \\
Present & \\
Prcomatoid features & \\
\hline & \\
&
\end{tabular}

chromosome $19(\mathrm{HR}=3.9, p<0.001)$, in chromosome 20 $(\mathrm{HR}=4.1, p=0.01)$, and in chromosome $22(\mathrm{HR}=3.1$, $p=0.01)$, and insertions in chromosome $18(\mathrm{HR}=3.8, p=0.03)$ were independently associated with worse CSS. Sensitivity analyses were performed on 131 patients with abnormal karyotype. No statistically significant baseline differences were recorded between patients with normal and abnormal karyotype. In survival analyses, both Kaplan-Meier plots and MCR models recorded virtually the same results.

\section{Discussion}

This study investigated one of the largest cohorts to date with complete karyotype analysis. Noteworthy, our results benefitted of an extended follow-up time, significantly longer relatively to previous reports (5-10). This longer follow-up represents a strength of this study and supports our findings, especially considering that RCC may have a long course and risk of relapse may still be present even after several years following surgery $(11,12)$. Additionally, a long 


\section{Frequencies of chromosomal abnormalities}

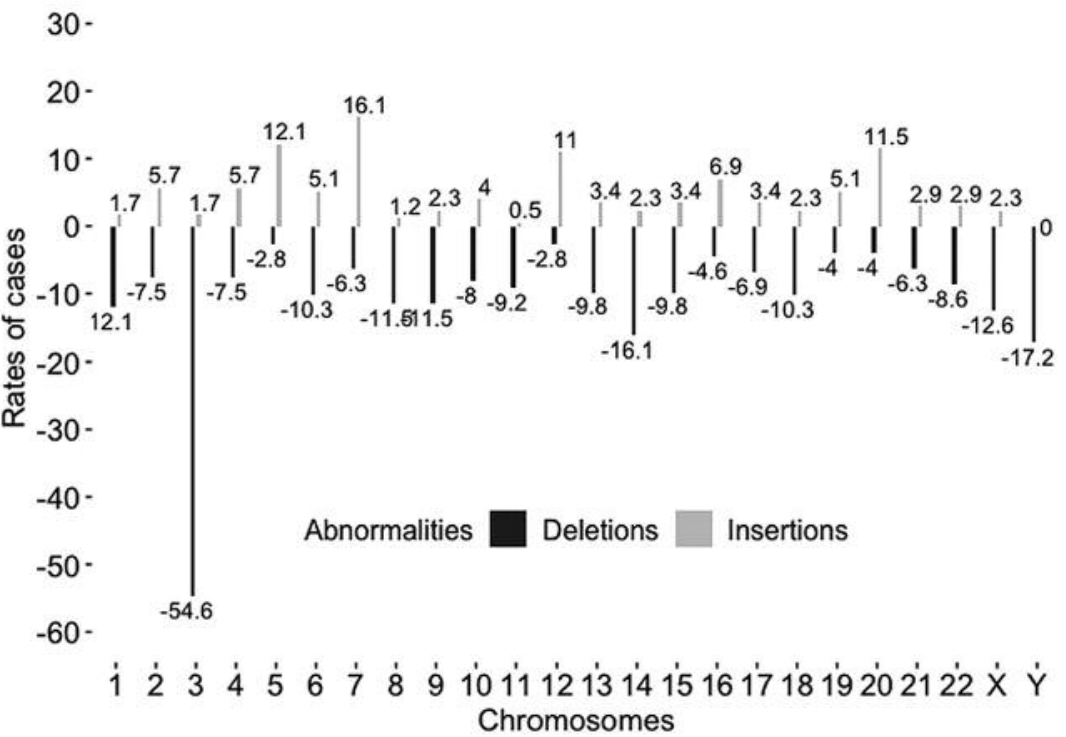

Figure 1. Chromosomal abnormalities distribution rates among a cohort of 174 clear cell renal cell carcinoma patients with abnormal karyotype. Positive values indicate insertions abnormalities. Negative values indicate deletions abnormalities.

Table II. Univariate and multivariate Cox regression models predicting cancer-specific survival according to presence vs. absence of specific chromosomal abnormalities. In multivariate analyses, adjustment variables consisted of TNM stage (I/II vs. III/IV), Fuhrman grade (G1/G2 vs. G3/G4) and sarcomatoid features (absent vs. present).

\begin{tabular}{|c|c|c|c|c|c|c|}
\hline \multirow[b]{2}{*}{ Chromosome abnormalities } & \multicolumn{3}{|c|}{ Univariate } & \multicolumn{3}{|c|}{ Multivariate } \\
\hline & HR & $95 \% \mathrm{CI}$ & $p$-Value & HR & $95 \% \mathrm{CI}$ & $p$-Value \\
\hline Loss 2 (present vs. absent) & 3.8 & $1.7-8.6$ & 0.001 & 7.5 & $2.8-19.9$ & $<0.001$ \\
\hline Loss 19 (present $v s$. absent) & 6.4 & $2.5-16.7$ & $<0.001$ & 3.9 & $1.4-10.9$ & 0.009 \\
\hline Loss 20 (present $v s$. absent) & 3.9 & $1.4-11.1$ & 0.009 & 4.1 & $1.4-12.4$ & 0.01 \\
\hline Loss 22 (present $v s$. absent) & 2.7 & $1.2-6.3$ & 0.03 & 3.1 & $1.3-7.6$ & 0.01 \\
\hline Gain 10 (present $v s$. absent) & 3.2 & $1.1-9.0$ & 0.03 & 2.1 & $0.7-6.3$ & 0.2 \\
\hline Gain 18 (present $v s$. absent) & 3.8 & $1.2-12.6$ & 0.02 & 3.8 & $1.1-12.9$ & 0.03 \\
\hline
\end{tabular}

HR: Hazard ratio; CI: confidence interval.

follow-up period may better highlight the prognostic role of chromosomal abnormalities over other well-established prognostic factors such as stage and grading.

Our analyses resulted in several noteworthy findings. First, deletions in chromosome 3 were the most typical chromosomal imbalance, with monosomy 3 or deletions of $3 p$ representing the most frequent alterations. These findings are in agreement with all previous reports $(6,9,10,14,15)$, where deletions of chromosome 3 represented the most common chromosomal aberration, ranging from $43.7 \%$ (15) to $99 \%$ (10). The loss of $3 p$ is a characteristic abnormality in ccRCC (16). Additionally, chromosome $3 p$ loss encompassing the von Hippel-Lindau (VHL) gene are observed in the majority of sporadic ccRCC (17). The inactivation of the VHL gene has been associated with better prognosis $(6,18,19)$. Our findings did not confirm such relationship and showed that deletions in chromosome 3 were not predictors of M1 stage, high grade, sarcomatoid features, or survival. The discordance with other reports $(6$, 14) may be explained by the fact that other abnormalities that occur in subsequent phases may have a more pronounced prognostic relevance.

Second, other frequent chromosomal abnormalities were deletions in chromosomes $\mathrm{Y}$ and 14 and insertions in 

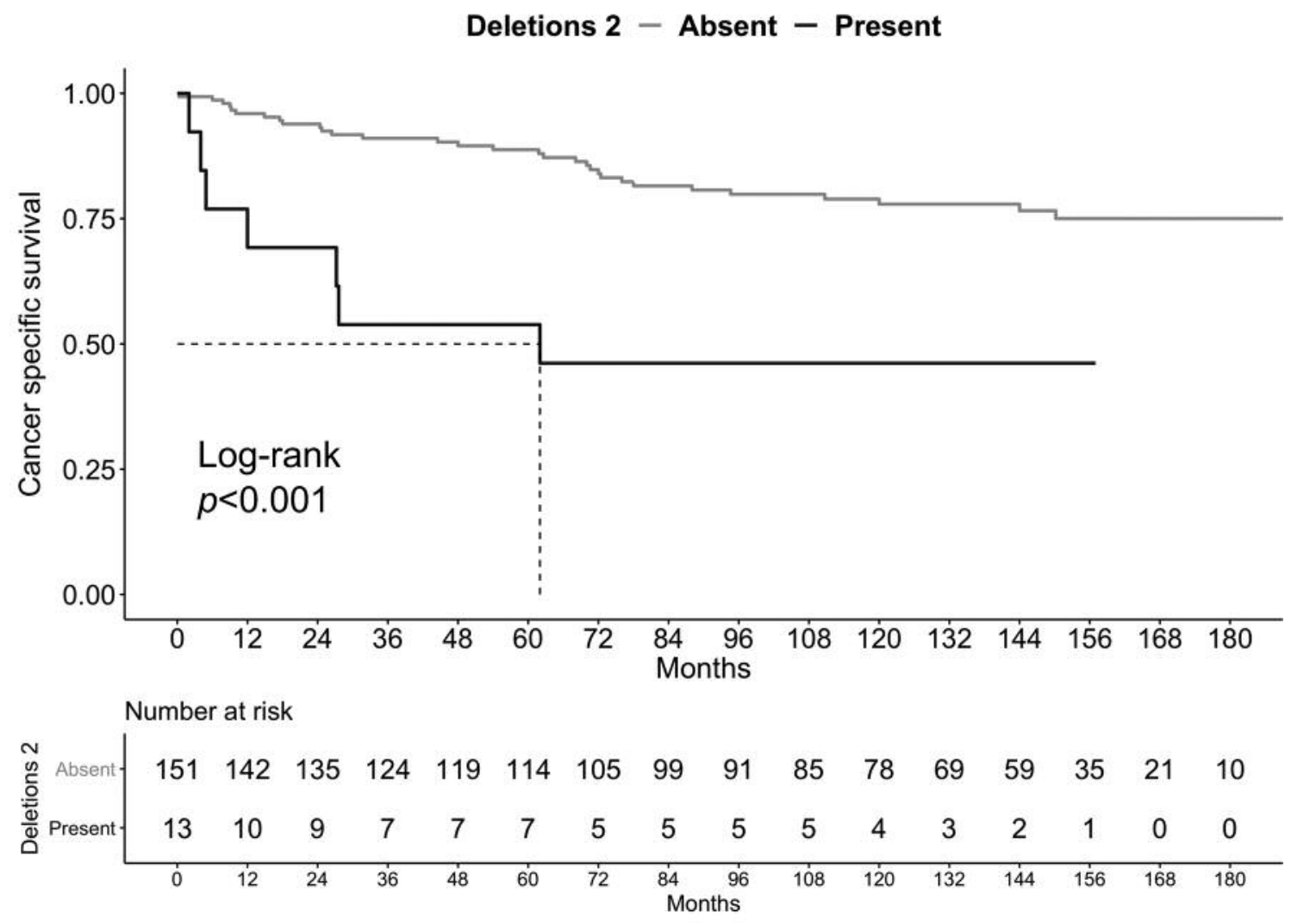

Deletions 22 - Absent - Present
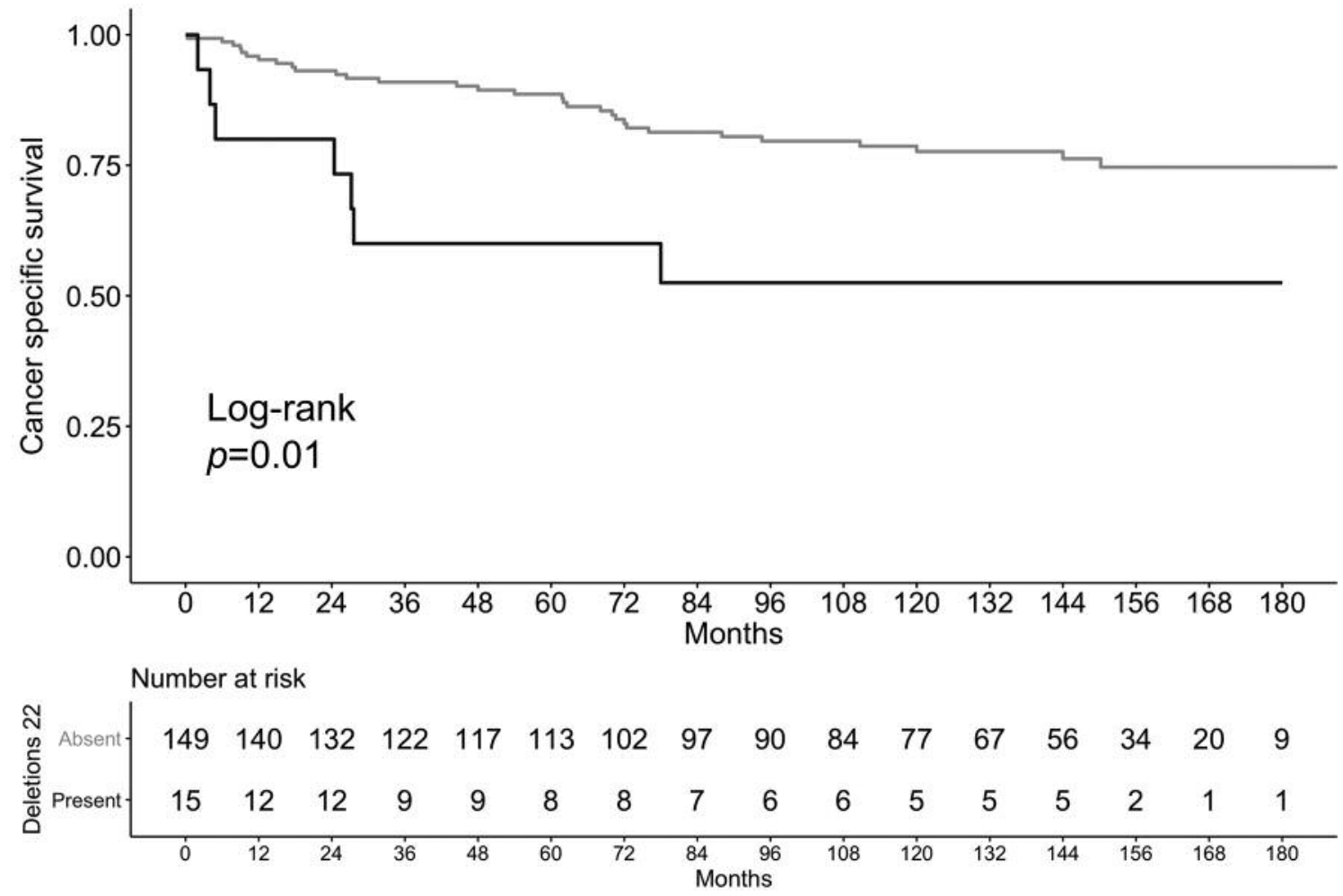

Figure 2. Continued 

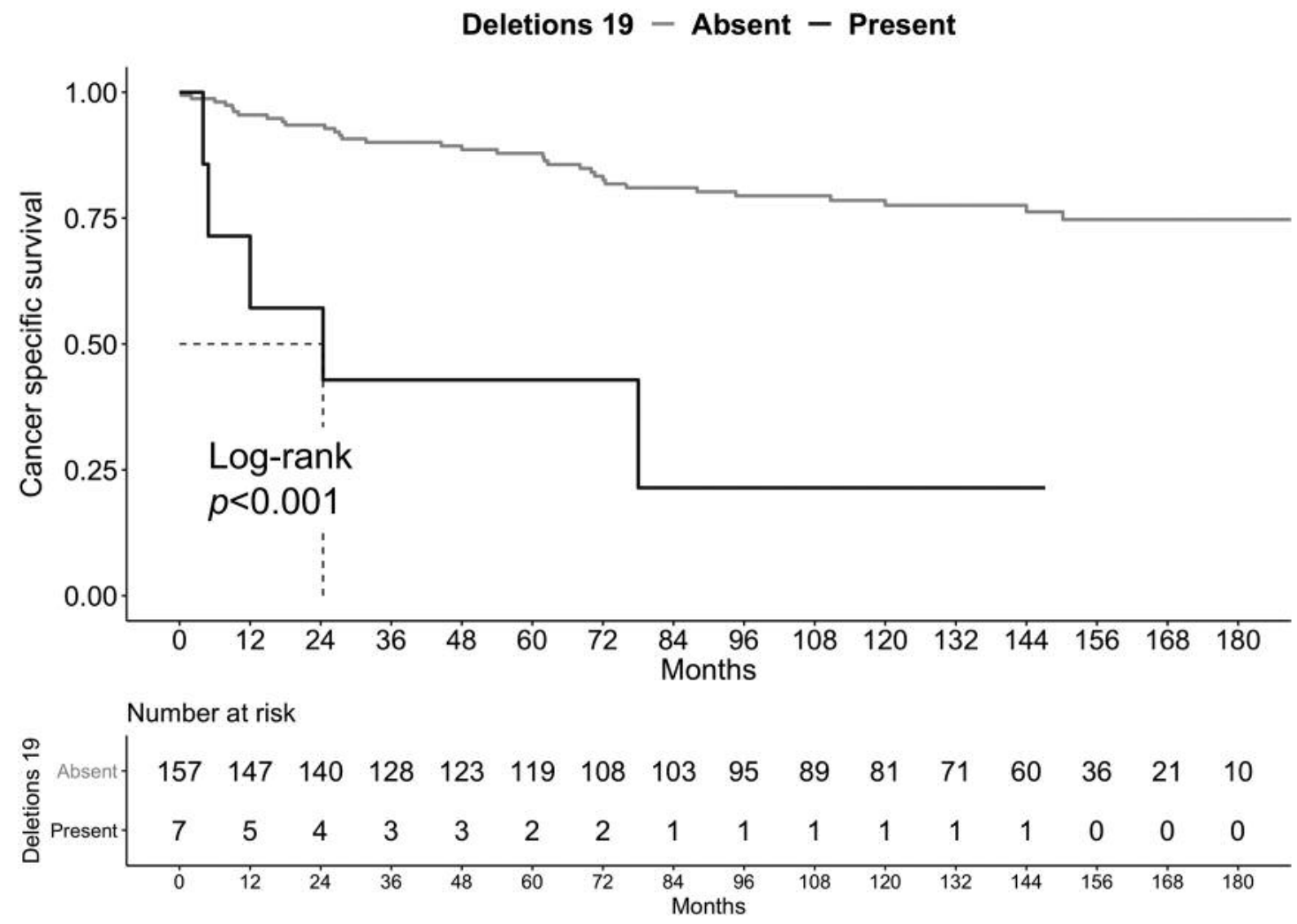

\section{Insertions 10 - Absent - Present}

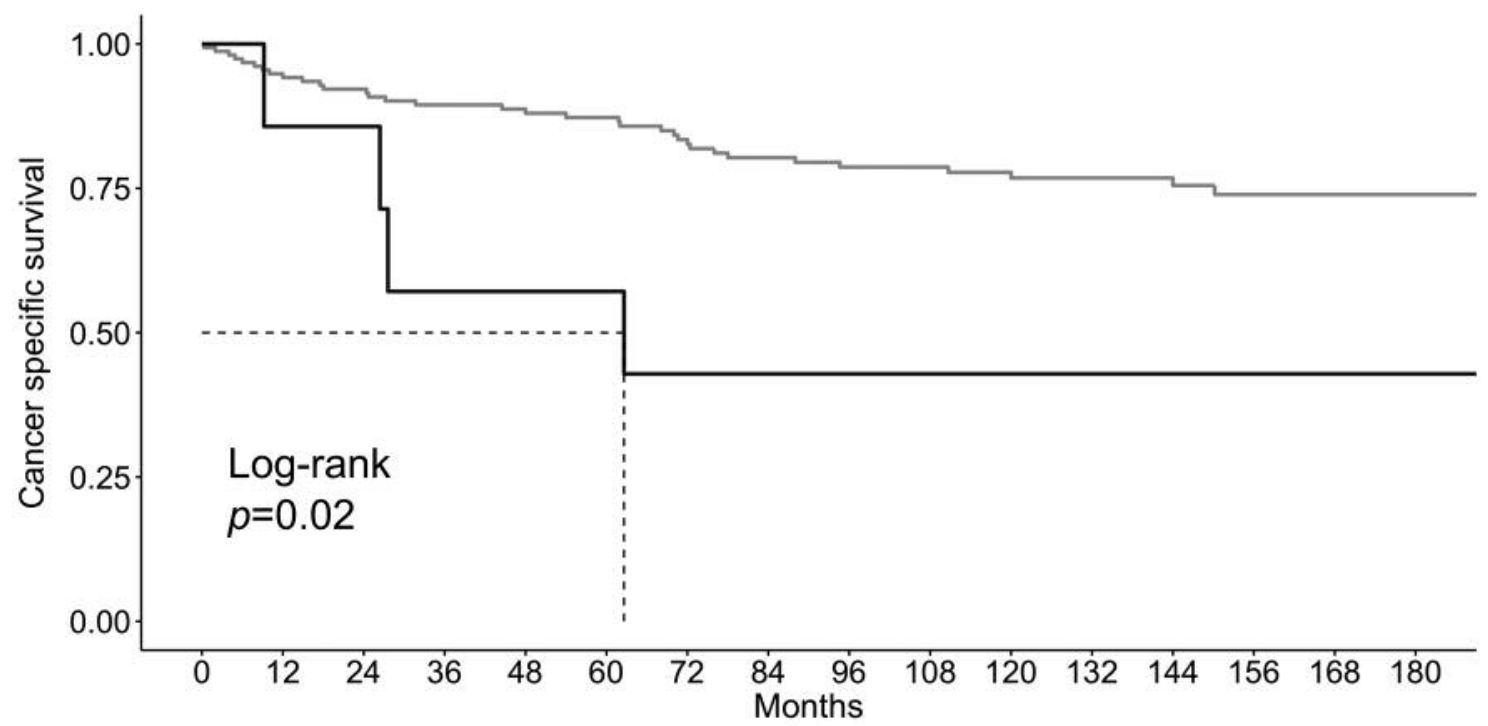

Number at risk

\begin{tabular}{|c|c|c|c|c|c|c|c|c|c|c|c|c|c|c|c|c|}
\hline \multirow{3}{*}{ 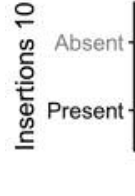 } & \multirow[b]{2}{*}{7} & \multirow{2}{*}{$\begin{array}{c}146 \\
6\end{array}$} & \multirow{2}{*}{$\begin{array}{c}138 \\
6\end{array}$} & \multirow{2}{*}{$\begin{array}{c}127 \\
4\end{array}$} & \multirow{2}{*}{$\begin{array}{c}122 \\
4\end{array}$} & \multirow{2}{*}{$\begin{array}{c}117 \\
4\end{array}$} & \multirow{2}{*}{$\begin{array}{c}107 \\
3\end{array}$} & \multirow{2}{*}{$\begin{array}{c}101 \\
3\end{array}$} & \multirow{2}{*}{$\begin{array}{c}93 \\
3\end{array}$} & \multirow{2}{*}{$\begin{array}{c}88 \\
2\end{array}$} & \multirow{2}{*}{$\begin{array}{c}80 \\
2\end{array}$} & \multirow{2}{*}{$\begin{array}{l}70 \\
2\end{array}$} & \multirow{2}{*}{$\begin{array}{c}59 \\
2\end{array}$} & \multirow{2}{*}{$\begin{array}{c}35 \\
1\end{array}$} & \multirow{2}{*}{$\begin{array}{c}20 \\
1\end{array}$} & \multirow{2}{*}{$\begin{array}{l}9 \\
1\end{array}$} \\
\hline & & & & & & & & & & & & & & & & \\
\hline & 0 & 12 & 24 & 36 & 48 & 60 & 72 & 84 & $\begin{array}{r}96 \\
\text { ths }\end{array}$ & 108 & 12 & 13 & 14 & 15 & 16 & 180 \\
\hline
\end{tabular}

Figure 2. Continued 
Deletions 20 - Absent - Present

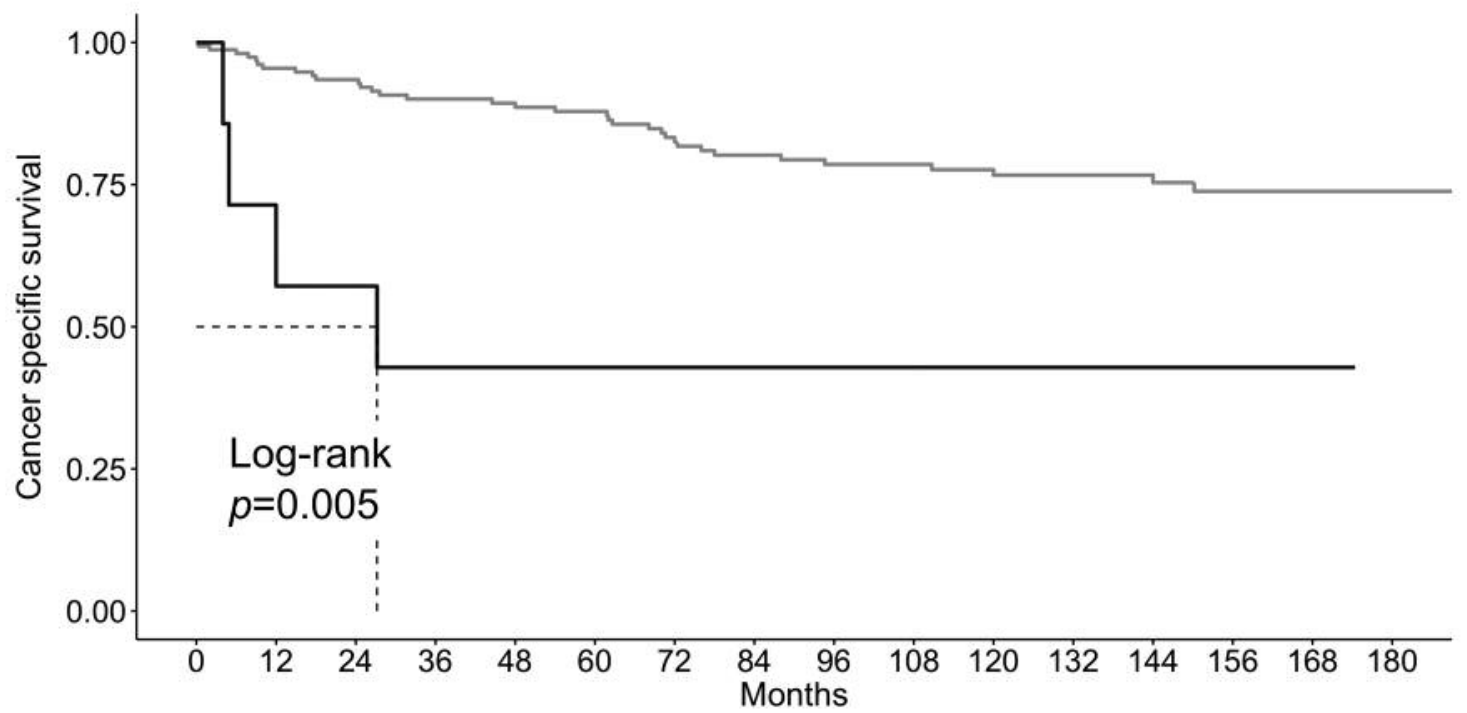

Number at risk

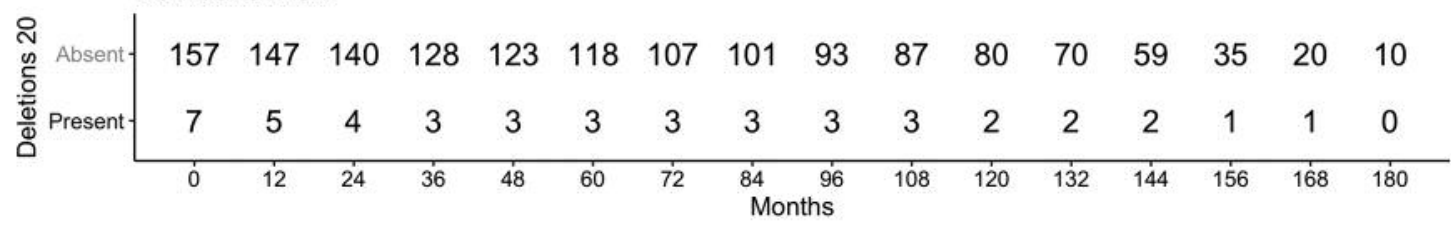

Insertions 18 - Absent - Present

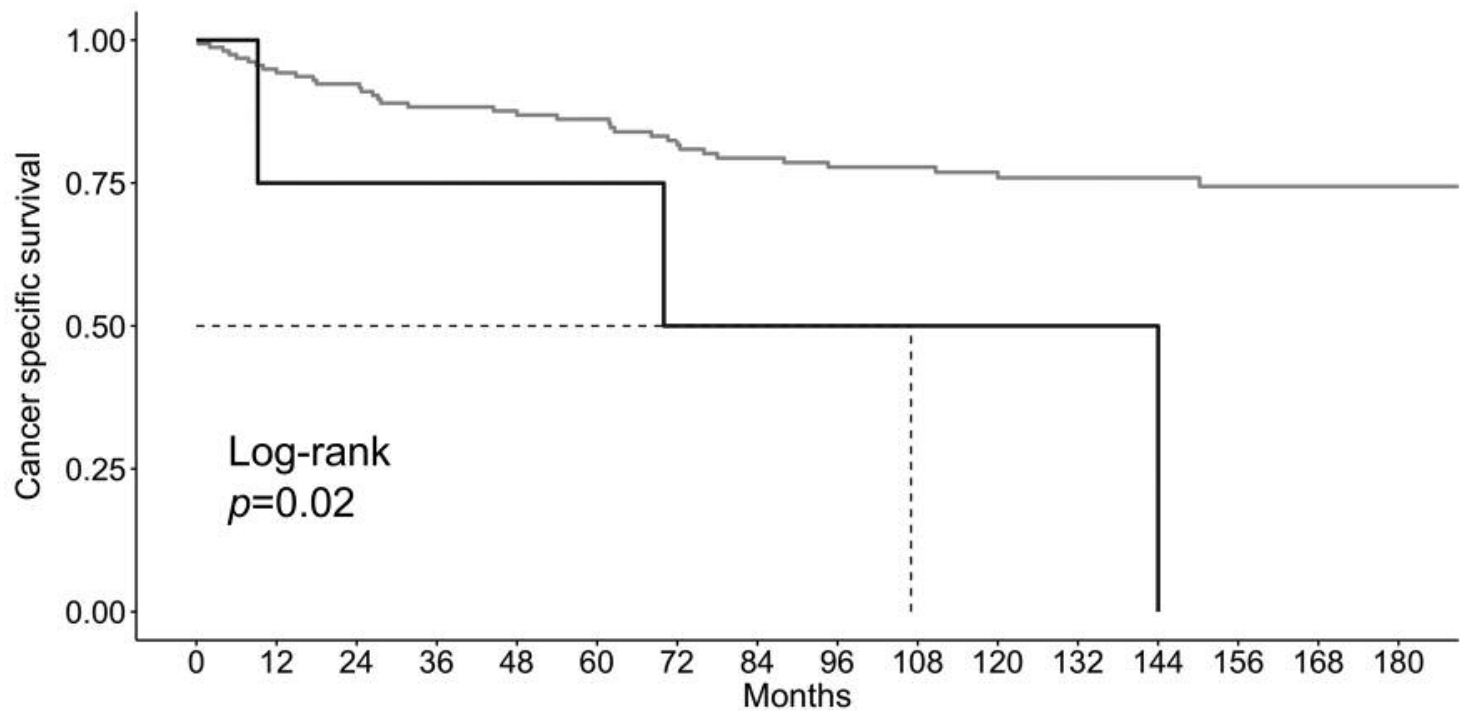

Number at risk

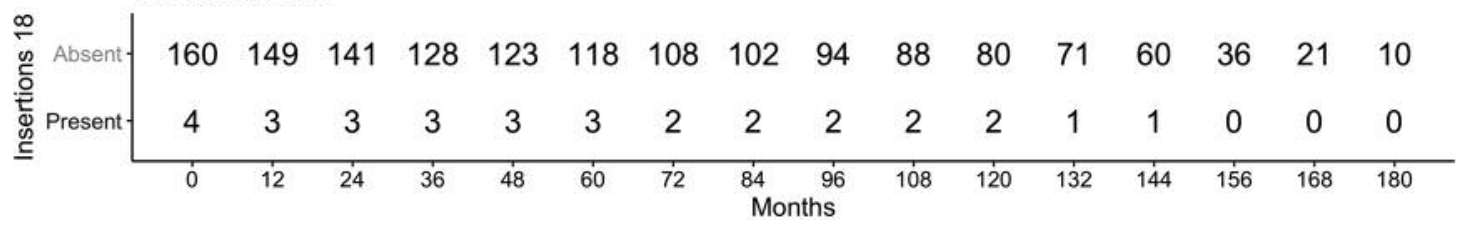

Figure 2. Kaplan-Meier plots depicting cancer-specific survival among a cohort of 174 clear cell renal cell carcinoma patients with available karyotype analysis, according to presence vs. absence of specific chromosomal abnormalities. 
chromosome 7 , which accounted for $17.2 \%, 16.1 \%$ and $16.1 \%$ of all abnormal karyotypes, respectively, followed by deletions in chromosomes 6, 8, 9 and $\mathrm{X}$, as well as insertions in chromosomes 5 and 20. These findings are in agreement with previous reports $(6,10,14,15)$ and further confirm the extreme heterogeneity of ccRCC tumors. In univariate logistic regression analyses, deletions in chromosome 9 were associated with metastatic stage, deletions in chromosomes 6, 10 and 11 and insertions in chromosome 5 with higher Fuhrman grade and deletions in chromosomes 2 and 18 with sarcomatoid features. Due to the low number of observations and events, these associations need to be interpreted with caution. Nonetheless, some of these findings may be highly informative. For example, deletions in chromosome 9 have been reported to be associated with higher propensity of distant metastases $(6,8,9)$, as well as with worse prognosis $(6,8)$. Conversely, Gunawan et al. study (9) as well as this study did not show a significantly worse cancer specific survival in patients with deletions in chromosome 9. This discrepancy may be attributed to lower rates of events, compared to Klatte et al. (6). Additionally, it may also be postulated that deletions in chromosome 9 in our series did not involve loss of tumor suppressor genes on 9p (20), such as CDKN2A gene.

Third, survival analyses confirmed our previous findings (5), showing a significantly worse cancer specific survival in patients with deletions in chromosomes 19, 20 and 22, which also independently predicted worse survival. These findings further corroborated the possible involvement of secondary alterations that may have led to RCC progression. Additionally, in these updated analyses, also deletions in chromosome 2 and insertions in chromosomes 10 and 18 were associated with worse CSS. Even if no definitive conclusions could be drawn because of the relative rarity of events, it is interesting to note that deletions in chromosome 2 were also associated with significantly higher rates of sarcomatoid features, which are well-established adverse risk factors (21).

Recent studies, such as the Cancer Genome Atlas Research Network (22) and the Tracking Renal Cell Cancer Evolution through therapy (TRACERx) Renal program (23), have contributed towards a deeper understanding of the molecular characterization of ccRCC. Alterations in the VHL tumor suppressor gene (located on chromosome 3) are the most frequent (24). Its inactivation leads to up-regulation of hypoxia-inducible factor (HIF) that promotes expression of angiogenic factors, lower rates of apoptosis, and higher rates of cellular proliferation. However, due to its ubiquitous role, no consistent relationship between VHL status and clinical outcome has been found (25), which may explain the lack of correlation with CSM in the present study. Additionally, the SWI/SNF chromatin remodeling complex has been found to be frequently mutated in ccRCC (26). Among the genes of this complex, PBRMI and ARIDIA are located on chromosome 3, while SMARCA4 is located on chromosome 19. This complex is involved in tumor suppression and its inactivation may amplify VHL inactivation by upregulating the HIF pathways leading to tumor progression.

Finally, the difference between our findings (5) and those of previous studies (6-8) reflect the extreme heterogeneity of karyotype alterations in ccRCC tumors. Our results relied on complete cytogenetic analysis that required culture of tumor cells and allowed an overview of the whole tumor karyotype. This method is actually rarely applied during clinical practice, but may serve as the basis for both the diagnosis and the application of target-directed methods, such as fluorescence in situ hybridization (FISH) and genome-wide analysis, which may further investigate these specific alterations, as either diagnostic and prognostic tools.

Significant limitations of this study should be acknowledged. Despite the relative large sample size, the number of events for each chromosomal abnormality is still limited. Moreover, specific subgroup analyses according to pathological characteristics could not be performed with appropriate statistical power. Therefore, other prognostically relevant cytogenetic aberrations may have been masked by the presence of well-established pathological prognostic factors, such as stage, Fuhrman grade and presence of sarcomatoid features.

\section{Conflicts of Interest}

All the Authors declare no conflict of interest regarding this study.

\section{Authors' Contributions}

Conception and design: Alessandro Antonelli; Acquisition of data: Maria Furlan, Alessandro Veccia, Simone Francavilla, Stefania Zamboni; Analysis and interpretation of data: Carlotta Palumbo, Alessandro Antonelli, Maria Furlan, Alessandro Veccia, Simone Francavilla, Stefania Zamboni, Piera Balzarini, Regina Tardanico; Drafting of the manuscript: Carlotta Palumbo, Alessandro Antonelli; Statistical analysis: Carlotta; Palumbo; Critical revision of the manuscript for important intellectual content: Tiziano Zanotelli, Alberto Cozzoli, Piera Balzarini, Regina Tardanico, Claudio Simeone; Supervision: Alessandro Antonelli; Obtaining funding/ administrative support: None.

\section{References}

1 Moch H, Cubilla AL, Humphrey PA, Reuter VE and Ulbright TM: The 2016 WHO Classification of Tumours of the Urinary System and Male Genital Organs - Part A: Renal, Penile, and Testicular Tumours. Eur Urol 70: 93-105, 2016. PMID: 26935559. DOI: 10.1016/j.eururo.2016.02.029

2 Cheng L, Zhang S, MacLennan GT, Lopez-Beltran A and Montironi R: Molecular and cytogenetic insights into the pathogenesis, classification, differential diagnosis, and prognosis of renal epithelial neoplasms. Hum Pathol 40: 10-29, 2009. PMID: 19027455. DOI: 10.1016/j.humpath.2008.09.009 
3 Kovacs G, Akhtar M, Beckwith BJ, Bugert P, Cooper CS, Delahunt B, Eble JN, Fleming S, Ljungberg B, Medeiros LJ, Moch H, Reuter VE, Ritz E, Roos G, Schmidt D, Srigley JR, Störkel S, van den Berg E and Zbar B: The Heidelberg classification of renal cell tumours. J Pathol 183: 131-133, 1997. PMID: 9390023. DOI: 10.1002/(SICI)1096-9896(199710) 183:2<131::AID-PATH931>3.0.CO;2-G

4 Antonelli A, Tardanico R, Balzarini P, Arrighi N, Perucchini L, Zanotelli T, Cozzoli A, Zani D, Cunico SC and Simeone C: Cytogenetic features, clinical significance and prognostic impact of type 1 and type 2 papillary renal cell carcinoma. Cancer Genet Cytogenet 199: 128-133, 2010. PMID: 20471516. DOI: 10.1016/j.cancergencyto.2010.02.013

5 Antonelli A, Arrighi N, Tardanico R, Balzarini P, Zanotelli T, Corti S, Zani D, Cozzoli A, Cunico SC and Simeone C: Prognostic value of cytogenetic analysis in clear cell renal carcinoma: a study on 131 patients with long-term follow-up. Anticancer Res 30: 4705-4709, 2010. PMID: 21115928.

6 Klatte T, Rao PN, de Martino M, LaRochelle J, Shuch B, Zomorodian N, Said J, Kabbinavar FF, Belldegrun AS and Pantuck AJ: cytogenetic profile predicts prognosis of patients with clear cell renal cell carcinoma. J Clin Oncol 27: 746-753, 2009. PMID: 19124809. DOI: 10.1200/JCO.2007.15.8345

7 Klatte T, Kroeger N, Rampersaud EN, Birkhäuser FD, Logan JE, Sonn G, Riss J, Rao PN, Kabbinavar FF, Belldegrun AS and Pantuck AJ: Gain of chromosome 8q is associated with metastases and poor survival of patients with clear cell renal cell carcinoma. Cancer 118: 5777-5782, 2012. PMID: 22605478. DOI: $10.1002 / \mathrm{cncr} .27607$

8 La Rochelle J, Klatte T, Dastane A, Rao N, Seligson D, Said J, Shuch B, Zomorodian N, Kabbinavar F, Belldegrun A and Pantuck AJ: Chromosome 9p deletions identify an aggressive phenotype of clear cell renal cell carcinoma. Cancer 116: 46964702, 2010. PMID: 20629029. DOI: 10.1002/cncr.25279

9 Gunawan B, Huber W, Holtrup M, Heydebreck A von, Efferth T, Poustka A, Ringert R-H, Jakse G and Füzesi L: Prognostic Impacts of Cytogenetic Findings in Clear Cell Renal Cell Carcinoma: Gain of 5q31-qter Predicts a Distinct Clinical Phenotype with Favorable Prognosis. Cancer Res 61: 7731-7738, 2001. PMID: 11691785.

10 Monzon FA, Alvarez K, Peterson L, Truong L, Amato RJ, Hernandez-McClain J, Tannir N, Parwani AV and Jonasch E: Chromosome $14 \mathrm{q}$ loss defines a molecular subtype of clear-cell renal cell carcinoma associated with poor prognosis. Mod Pathol 24: 1470-1479, 2011. PMID: 21725288. DOI: 10.1038/ modpathol.2011.107

11 Antonelli A, Furlan M, Sodano M, Cindolo L, Belotti S, Tardanico R, Cozzoli A, Zanotelli T and Simeone C: Features, risk factors and clinical outcome of "very late" recurrences after surgery for localized renal carcinoma: A retrospective evaluation of a cohort with a minimum of 10 years of follow up. Int J Urol 23: 36-40, 2016. PMID: 26567050. DOI: 10.1111/iju.12962

12 Brookman-May S, May M, Shariat SF, Xylinas E, Stief C, Zigeuner R, Chromecki T, Burger M, Wieland WF, Cindolo L, Schips L, De Cobelli O, Rocco B, De Nunzio C, Feciche B, Truss M, Gilfrich C, Pahernik S, Hohenfellner M, Zastrow S, Wirth MP, Novara G, Carini M, Minervini A, Simeone C, Antonelli A, Mirone V, Longo N, Simonato A, Carmignani G and Ficarra V: Features associated with recurrence beyond 5 years after nephrectomy and nephron-sparing surgery for renal cell carcinoma: development and internal validation of a risk model (PRELANE score) to predict late recurrence based on a large multicenter database (CORONA/SATURN Project). Eur Urol 64: 472-477, 2013. PMID: 22748912. DOI: 10.1016/ j.eururo.2012.06.030

13 Antonelli A, Cozzoli A, Zani D, Zanotelli T, Nicolai M, Cunico SC and Simeone C: The follow-up management of nonmetastatic renal cell carcinoma: definition of a surveillance protocol. BJU Int 99: 296-300, 2007. PMID: 17326263.

14 Dagher J, Dugay F, Verhoest G, Cabillic F, Jaillard S, Henry C, Arlot-Bonnemains Y, Bensalah K, Oger E, Vigneau C, RiouxLeclercq $\mathrm{N}$ and Belaud-Rotureau MA: Histologic prognostic factors associated with chromosomal imbalances in a contemporary series of 89 clear cell renal cell carcinomas. Hum Pathol 44: 2106-2115, 2013. PMID: 23806527. DOI: 10.1016/ j.humpath.2013.03.018

15 Kuroda N, Tamura M, Shiotsu T, Nakamura S, Taguchi T, Tominaga A, Hes O, Michal M, Kawada C, Shuin T and Lee GH: Chromosomal abnormalities of clear cell renal cell carcinoma: Frequent gain of chromosome 7. Pathol Int 60: 9-13, 2010. PMID: 20055946. DOI: 10.1111/j.1440-1827.2009. 02467.x

16 Hirsch MS, Signoretti S and Dal Cin P: Adult renal cell carcinoma. Surg Pathol Clin 8: 587-621, 2015. PMID: 26612217. DOI: 10.1016/j.path.2015.09.003

17 Beroukhim R, Brunet J-P, Napoli AD, Mertz KD, Seeley A, Pires MM, Linhart D, Worrell RA, Moch H, Rubin MA, Sellers WR, Meyerson M, Linehan WM, Kaelin WG and Signoretti S: Patterns of gene expression and copy-number alterations in vonhippel lindau disease-associated and sporadic clear cell carcinoma of the kidney. Cancer Res 69: 4674-4681, 2009. PMID: 19470766. DOI: 10.1158/0008-5472.CAN-09-0146

18 Yao M, Yoshida M, Kishida T, Nakaigawa N, Baba M, Kobayashi K, Miura T, Moriyama M, Nagashima Y, Nakatani Y, Kubota Y and Kondo KI: VHL tumor suppressor gene alterations associated with good prognosis in sporadic clear-cell renal carcinoma. J Natl Cancer Inst 94: 1569-1575, 2002. PMID: 12381710.

19 Parker AS, Cheville JC, Lohse CM, Igel T, Leibovich BC and Blute ML: Loss of expression of von Hippel-Lindau tumor suppressor protein associated with improved survival in patients with early-stage clear cell renal cell carcinoma. Urology 65 : 1090-1095, 2005. PMID: 15893810. DOI: 10.1016/j.urology. 2004.12.040

20 Sandlund J, Oosterwijk E, Grankvist K, Oosterwijk-Wakka J, Ljungberg B and Rasmuson T: Prognostic impact of carbonic anhydrase IX expression in human renal cell carcinoma. BJU Int 100: 556-560, 2007. PMID: 17608827. DOI: 10.1111/j.1464410X.2007.07006.X

21 Tan PH, Cheng L, Rioux-Leclercq N, Merino MJ, Netto G, Reuter VE, Shen SS, Grignon DJ, Montironi R, Egevad L, Srigley JR, Delahunt B and Moch H: Renal tumors. Am J Surg Pathol 37: 1518-1531, 2013. PMID: 24025522. DOI: 10.1097/PAS.0b013e318299f12e

22 Cancer Genome Atlas Research Network. Comprehensive molecular characterization of clear cell renal cell carcinoma. Nature 499(7456): 43-49, 2013. PMID: 23792563. DOI: 10.1038 /nature 12222

23 Turajlic S, Xu H, Litchfield K, Rowan A, Horswell S, Chambers T, O’Brien T, Lopez JI, Watkins TBK, Nicol D, Stares M, 
Challacombe B, Hazell S, Chandra A, Mitchell TJ, Au L, Eichler-Jonsson C, Jabbar F, Soultati A, Chowdhury S, Rudman S, Lynch J, Fernando A, Stamp G, Nye E, Stewart A, Xing W, Smith JC, Escudero M, Huffman A, Matthews N, Elgar G, Phillimore B, Costa M, Begum S, Ward S, Salm M, Boeing S, Fisher R, Spain L, Navas C, Grönroos E, Hobor S, Sharma S, Aurangzeb I, Lall S, Polson A, Varia M, Horsfield C, Fotiadis N, Pickering L, Schwarz RF, Silva B, Herrero J, Luscombe NM, Jamal-Hanjani M, Rosenthal R, Birkbak NJ, Wilson GA, Pipek O, Ribli D, Krzystanek M, Csabai I, Szallasi Z, Gore M, McGranahan N, Van Loo P, Campbell P, Larkin J and Swanton C: Deterministic evolutionary trajectories influence primary tumor growth: TRACERx Renal. Cell 173: 595-610.e11, 2018. PMID: 29656894. DOI: 10.1016/j.cell.2018.03.057

24 D'Avella C, Abbosh P, Pal SK and Geynisman DM: Mutations in renal cell carcinoma. Urol Oncol Semin Orig Investig, 2018. PMID: 30478013. DOI: 10.1016/j.urolonc.2018.10.027
25 Mitchell TJ, Rossi SH, Klatte T and Stewart GD: Genomics and clinical correlates of renal cell carcinoma. World J Urol 36: 1899-1911, 2018. PMID: 30099580. DOI: 10.1007/s00345-0182429-x

26 Brugarolas J: Molecular genetics of clear-cell renal cell carcinoma. J Clin Oncol Off J Am Soc Clin Oncol 32: 19681976, 2014. PMID: 24821879. DOI: 10.1200/JCO.2012.45.2003

Received May 5, 2019

Revised May 19, 2019

Accepted May 20, 2019 